\title{
Assessment of Turkish women's knowledge concerning folic acid and prevention of birth defects
}

\author{
Nurhan Unusan* \\ Selcuk University, Education Faculty, Konya, Turkey
}

Submitted 12 May 2003: Accepted 3 March 2004

\begin{abstract}
Objectives: In Turkey, the incidence of neural tube defects (NTDs) is 30.1 per 10000 births. For this reason it seems an important problem for women of childbearing age. Adequate periconceptional consumption of folic acid could prevent NTDs. Most women are unaware of this recommendation. The objectives of this study were to evaluate women' knowledge and beliefs with regard to folic acid, and to estimate the consumption frequency of vitamin supplements periconceptionally and during the first trimester of pregnancy.

Design: Eight hundred and eighteen married women who had delivered a live-born infant within the previous 12 months completed the questionnaire. Each subject participated in a 20 -minute interview, with the questionnaire comprising multiplechoice statements. A random sample of 10 public health centres was drawn from 27 in three districts in Konya where about $50 \%$ of the population lives.

Results: Only 22\% of subjects had heard or read about folic acid. Thirteen per cent of women indicated knowledge of the direct link between folic acid supplementation and NTD prevention. The knowledge was greatest among 26- to 35-year-olds. Women with a university degree were more likely to have heard about folic acid than were less-educated women.

Conclusion: The results indicate that further government efforts are needed to inform the population and promote the optimal use of folic acid supplements and folateenriched foods. It is the responsibility of national authorities to increase health education concerning folic acid and the prevention of NTDs in their countries.
\end{abstract}

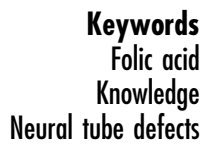

Folic acid

Knowledge Neural tube defects
The term neural tube defect (NTD) refers to any malformation of the embryonic brain and/or spinal cord. Spina bifida, anencephaly and encephalocele, known NTDs, are characterised by incomplete development of the central nervous system and its closely surrounding structures. Anencephaly generally causes death in utero or during the first few days after birth. In other types of NTD, the spinal cord lacks its normal covering of meninges, bone and skin, and significant neurological deficits are inevitable ${ }^{1}$. NTDs are accepted as among the most common birth defects contributing to infant mortality and severe congenital abnormalities. Unfortunately, since there is no registry system for births in Turkey and only $60 \%$ of all births occur at a health centre, registration of congenital abnormalities has not been possible so far. The incidence of NTDs is 30.1 per 10000 births in Turkey ${ }^{2}$, whereas NTDs occur in approximately 1 in 1000 births in the USA ${ }^{3}$. Turkey has a very high prevalence of NTDs compared with the EUROCAT registries ${ }^{4}$. Maternal illiteracy, advanced age and residence in northern and eastern regions of Turkey have been shown to be risk factors for NTDs. The geographical distribution of NTDs in this country shows a relationship between socio-economic status and environmental factors in the development of NTDs $^{2}$.

Folic acid, also known as pteroylmonoglutamic acid, is a synthetic compound used in dietary supplements and fortified foods. The term folate includes all compounds that have the vitamin properties of folic acid - including naturally occurring compounds in food and folic acid 5 . Folate functions as a coenzyme in one-carbon transfer reactions in the metabolism of amino and nucleic acids. Pregnancy is associated with a marked acceleration in one-carbon transfer reactions for nucleotide synthesis and cell division ${ }^{6}$. Epidemiological studies show an association of preconceptional and early postconceptional vitamin status and the risk of occurrence of NTDs ${ }^{7-16}$. Because in Turkey more than $30 \%$ of pregnancies are unplanned and 95\% of NTDs are first-time occurrences, preconceptional nutritional status appears to be especially important (www.die.gov.tr). The embryonic neural tube is formed 20-28 days after fertilisation, at a time when a woman may not know she is pregnant. Increased cell division associated with the rapidly growing foetus and placenta 
occurs in addition to an expansion of maternal red blood cells and the size of reproductive organs. It is therefore important to ensure adequate folate intake during pregnancy to prevent maternal folate depletion, which would allow for adequate foetal supplies for growth and development ${ }^{6}$. In a longitudinal study in Turkey, blood samples were analysed for folate in pre- and postnatal women. The subjects were selected randomly during the 13 th to 17 th week of gestation and were followed up at 28-32 weeks' gestation and 13-17 weeks postpartum. Risk of folate deficiency was found among 59.7\% of subjects during early pregnancy, $76.4 \%$ during late pregnancy and $73.3 \%$ at the postpartum stage ${ }^{17}$.

Folate is present in many foods. Liver, yeast and bread containing yeast, eggs, beans, oranges, and a wide range of fruits and green leafy vegetables, are good sources. Although orange juice is not a good source of folate, since it is consumed in large amounts it accounts for a significant portion of the daily intake ${ }^{1}$. The main dietary sources of folate for women in Turkey are given in Table $1^{18}$. The most important parameters influencing food consumption pattern are income level and lack of knowledge. While low-income families consume more cereal, high-income families eat more meat, fish, eggs and milk, fresh fruits and vegetables. As a result, the problem of folate deficiency comes from the uneven distribution of foods among socioeconomic, gender and age groups ${ }^{19}$.

Additional intake of foods rich in folate might raise the average intake, but it is not clear that increased consumption of foods would prevent NTDs as effectively as a daily vitamin supplement containing $400 \mu \mathrm{g}$ folic $\operatorname{acid}^{20}$. When synthetic folic acid is consumed as a supplement without food, it is approximately $100 \%$ bioavailable $^{21}$. On the other hand, when folic acid is consumed with food, bioavailability is nearly $85 \%{ }^{22}$. Brouwer et $a l^{23}$ showed that when folate $\left(350 \mu \mathrm{g} \mathrm{day}^{-1}\right)$ and folic acid $\left(250 \mu \mathrm{g} \mathrm{day}^{-1}\right)$ are consumed, the relative bioavailability of dietary folate compared with folic acid is $60-98 \%$, depending on the endpoint used. These researchers advised to increase the consumption of vegetables and citrus fruit to improve folate status.

It is also worthwhile noting that a population increase in folic acid intake might also have a protective effect on

Table 1 Contribution made by food groups to the dietary folate content of household food in Turkey: national averages

\begin{tabular}{lc}
\hline Source & Dietary \\
\hline Cereal-based products & \% of total) \\
Meat-based products & 33.2 \\
Fish-based products & 2.4 \\
Milk-based products and eggs & 0.2 \\
Fruits & 6.2 \\
Vegetables & 9.0 \\
Sugar-based products & 45.2 \\
Salt and herbs & 0.1 \\
Drinks & 0.2 \\
All other foods & 2.5 \\
\end{tabular}

macrocytic anaemia, cardiovascular disease, and pancreatic and breast cancer ${ }^{24}$.

The aim of the present study was to examine the knowledge and behaviours relevant to folate intake among Turkish women of childbearing age. The study had three objectives:

1. to explore the use of vitamin/mineral supplements preconceptionally and during the first trimester of pregnancy;

2. to determine the knowledge and awareness of folate among women; and

3. to examine women's knowledge and awareness of folate by demographic status, including age and educational status.

\section{Methods}

The study took place in Central Anatolia, where the incidence of NTDs is 31.9 per 10000 births $^{2}$. The sample consisted of 818 married women who had delivered a liveborn infant within the previous 12 months. Women below 18 years of age and women whose child was older than 12 months were excluded. Each subject participated in a 20minute interview concerning folate during June to September 2002. The 24-item interview script examined subjects' supplement use and knowledge about folate ${ }^{25,26}$. The questionnaire comprised only multiple-choice statements. No identification data were required. The questionnaire consisted of two parts: (1) a demographic section that included age and educational status; and (2) a section on knowledge and actual usage of folic acid in the last pregnancy.

A random sample of 10 public health centres was drawn from 27 in three districts in Konya where about $50 \%$ of the population lives. The author and 20 trained, final-year university students conducted the interviews with mothers. The questionnaire was field-tested among 97 female patients from January to March 2002, resulting in minor modifications.

Analysis was completed using SPSS for Windows 10.0 (SPSS Inc., Chicago, IL, USA). For all analyses $P<0.05$ is used to indicate statistical significance. Categorical data are reported as percentages and analysed using chi-square statistics.

\section{Results}

In 1997, the duration of compulsory basic education was extended to 8 years that was formerly only 5 years. The current rate of primary school attendance in Turkey is $85.7 \%$. The demographic characteristics of the Turkish women participating in the study are given in Table 2 .

As can be seen from Table 3, on average only $22 \%$ of subjects had heard or read about folic acid, and 14.2\% could answer that folic acid is a vitamin. Only $13 \%$ of the 
Table 2 Distribution of education level across age groups. Data are expressed as \% $(n)$

\begin{tabular}{llrrrr}
\hline & \multicolumn{5}{c}{ Age group (years) } \\
\cline { 2 - 6 } Education level & $18-25$ & $26-30$ & $31-35$ & $36-40$ & $41-45$ \\
\hline Primary school & $17.3(60)$ & $19.7(68)$ & $17.9(62)$ & $22.5(78)$ & $22.5(78)$ \\
High school & $30.5(72)$ & $26.3(62)$ & $21.2(50)$ & $14.4(34)$ & $7.6(18)$ \\
University & $55.1(130)$ & $16.9(40)$ & $15.3(36)$ & $6.8(16)$ & $5.9(14)$ \\
\hline
\end{tabular}

women stated that folic acid could prevent birth defects. The knowledge was greatest among 26- to 35-year-olds and lowest among 41- to 45-year-olds.

Only 19\% of respondents could indicate the need for folic acid supplementation before pregnancy. The 18-25 year age group was the most likely to identify this link. The group of 26- to 30-year-olds had the greatest consumption of supplements containing folic acid for 1-3 months before getting pregnant, but it was only once a week. The same group was the one most likely to continue taking the supplement containing folic acid during the first three months of pregnancy.
Knowledge of folic acid was lowest among women aged $41-45$ years $(12.7 \%)$ and highest among women aged 26-30 (28.2\%). Among all women, 2.2\% were told about folic acid by their doctor, nurse or staff at the health clinic; 7.8\% heard about it through the media (television, radio, newspaper and magazines); and 3.3\% heard about it through friends. Brochures were the least effective method $(0.7 \%)$. Some $8.6 \%$ of respondents reported that they heard about folic acid when they were in school.

A difference in knowledge about folic acid by mother's education was quite clear, with prevalence of knowledge varying directly by subjects' education level (Table 4). Women with a university degree were more likely to have heard about folic acid than were women who attended primary school (49.2\% vs. 6.9\%). All responses were significant $(P<0.05)$. University graduates were able to correctly identify good dietary sources of folic acid, compared with high school and primary school graduates. All respondents failed to identify three poor dietary sources (beans and peas, milk and milk products, meat and meat products) of folic acid.

Table 3 Knowledge of neural tube defects and use of periconceptional folic acid supplementation. Data are yes responses, expressed as \% $(n)$

\begin{tabular}{|c|c|c|c|c|c|c|}
\hline \multirow[b]{2}{*}{ Question } & \multicolumn{5}{|c|}{ Age group (years) } & \multirow[b]{2}{*}{$P$-value } \\
\hline & $18-25$ & $26-30$ & $31-35$ & $36-40$ & $41-45$ & \\
\hline Have you ever heard of folic acid? & $27.5(72)$ & $28.2(48)$ & $23.0(34)$ & $18.8(24)$ & $12.7(14)$ & 0.009 \\
\hline \multicolumn{7}{|l|}{$\begin{array}{l}\text { From which source did you get } \\
\text { the information on folic acid? }\end{array}$} \\
\hline TV & $3.8(10)$ & $3.5(6)$ & $2.7(4)$ & $1.6(2)$ & $3.6(4)$ & 0.001 \\
\hline Radio & $1.5(4)$ & $1.2(2)$ & & & & \\
\hline Newspaper & $0.8(2)$ & & $2.7(4)$ & $3.1(4)$ & $3.6(4)$ & \\
\hline Magazines & $2.3(6)$ & $3.5(6)$ & $2.7(4)$ & $1.6(2)$ & & \\
\hline Doctor. nurse or health clinic staff & $3.1(8)$ & $3.5(6)$ & $1.4(2)$ & $3.1(4)$ & & \\
\hline Friend & $8.4(22)$ & $2.4(4)$ & $4.1(6)$ & $1.6(2)$ & & \\
\hline Brochures/posters & & & & $1.6(2)$ & $1.8(2)$ & \\
\hline School & $8.4(22)$ & $14.1(24)$ & $10.8(16)$ & $6.3(8)$ & $3.6(4)$ & \\
\hline \multicolumn{7}{|l|}{ Do you know what folic acid is? } \\
\hline Vitamin & $16.8(44)$ & $17.6(30)$ & $21.6(32)$ & $7.8(10)$ & $7.3(8)$ & 0.001 \\
\hline Mineral & $3.8(10)$ & $5.9(10)$ & & $6.3(8)$ & $1.8(2)$ & \\
\hline \multicolumn{7}{|l|}{$\begin{array}{l}\text { When is the best time to take } \\
\text { folic acid supplement? }\end{array}$} \\
\hline Before pregnancy & $25.2(66)$ & $20(34)$ & $21.6(32)$ & $15.6(20)$ & $10.9(12)$ & 0.005 \\
\hline During pregnancy & $0.8(2)$ & $3.5(6)$ & $1.4(2)$ & $1.6(2)$ & & \\
\hline \multicolumn{7}{|l|}{$\begin{array}{c}\text { Which of the following diseases is } \\
\text { prevented by taking folic acid? }\end{array}$} \\
\hline Diabetes & $1.5(4)$ & & & & & 0.001 \\
\hline Cancer & $7.6(20)$ & $2.4(4)$ & $1.4(2)$ & $1.6(2)$ & $1.8(2)$ & \\
\hline Neural tube defects & $13(34)$ & $17.6(30)$ & $17.6(26)$ & $10.9(14)$ & $5.5(6)$ & \\
\hline Coronary heart disease & & $1.2(2)$ & & & & \\
\hline $\begin{array}{l}\text { Did you take a supplement containing folic } \\
\text { acid for } 1-3 \text { months before getting pregnant? }\end{array}$ & $1.5(4)$ & $7.1(12)$ & $4.1(6)$ & & $1.8(2)$ & 0.001 \\
\hline \multicolumn{7}{|l|}{$\begin{array}{l}\text { How often did you take a supplement } \\
\text { containing folic acid before getting pregnant? }\end{array}$} \\
\hline Once a week & $1.5(4)$ & $5.9(10)$ & $1.4(2)$ & $1.6(2)$ & & 0.007 \\
\hline Two-three times a week & $1.5(4)$ & $2.4(4)$ & $4.1(6)$ & $1.6(2)$ & & \\
\hline Every day & $1.5(4)$ & $2.4(4)$ & $4.1(6)$ & $1.6(2)$ & & \\
\hline $\begin{array}{l}\text { Did you take a supplement containing folic } \\
\text { acid for } 1-3 \text { months of pregnancy? }\end{array}$ & $1.5(4)$ & $8.2(14)$ & $4.1(6)$ & $6.3(8)$ & $5.5(6)$ & 0.001 \\
\hline \multicolumn{7}{|l|}{ How often did you take prenatal supplements? } \\
\hline Once a week & $1.5(4)$ & $2.4(4)$ & & $1.6(2)$ & & 0.001 \\
\hline Two-three times a week & & $2.4(4)$ & & $3.1(4)$ & & \\
\hline Every day & & $3.5(6)$ & $2.7(4)$ & & $3.6(4)$ & \\
\hline
\end{tabular}


Table 4 Knowledge and awareness of folate, by education level. Data are correct responses, expressed as \% $(n)$

\begin{tabular}{lccc}
\hline & \multicolumn{3}{c}{ Education level } \\
\cline { 2 - 4 } & \multicolumn{4}{c}{ High } & Primary \\
Question & University & school & school \\
\hline Do you know which of the following foods are rich in folic acid? \\
Green vegetables & $26.3(62)$ & $12.7(30)$ & $3.5(12)$ \\
Vegetables in general & $17.8(42)$ & $3.4(8)$ & $1.2(4)$ \\
Liver & $24.6(58)$ & $5.9(14)$ & $2.9(10)$ \\
Meat (excluding liver) & $7.6(18)$ & $4.2(10)$ & \\
Milk and milk products & $10.2(24)$ & $5.1(12)$ & \\
Grain products & $5.9(14)$ & $3.4(8)$ & $1.2(4)$ \\
Beans and peas & $10.2(24)$ & $5.1(12)$ & $1.7(6)$ \\
Citrus fruits & $22.9(54)$ & $10.2(24)$ & $2.9(10)$ \\
Fruits (excluding & $12.7(30)$ & $4.2(10)$ & $1.2(4)$ \\
$\quad$ citrus fruits) & & & \\
What is the best way to take folic acid/folate? & & \\
Both food and supplement & $22(52)$ & $7.6(18)$ & $3.5(12)$ \\
\hline
\end{tabular}

\section{Discussion}

The observation that, on average, only $13 \%$ of respondents knew that folic acid can prevent NTDs indicates a low level of awareness of this important public health message. The present data indicated clearly that university graduates are much better informed about the ability of folic acid to prevent NTDs. The results presented here indicate that, to improve knowledge such as when and how much folic acid should be consumed and which foods are rich sources of folate, it will be necessary to counsel women effectively in future practice. When asked to identify good dietary sources of folic acid, respondents recognised that all dietary items listed (orange juice, liver, green leafy vegetables, peas and beans) could contribute to folic acid intake.

According to results obtained by the Government Statistics Institute (www.die.gov.tr), at least 30\% of all pregnancies in Turkey are unplanned. However, only 19\% of respondents could identify the need for folic acid supplementation before pregnancy. These results are very disturbing because, for supplementation to succeed, knowledge must exist before planning a pregnancy. In addition, all age groups in this research were poorly informed. Some $13 \%$ of respondents indicated the folic acid-NTD prevention link, but only $2.9 \%$ reported that they used folic acid every day before pregnancy. Despite these disappointing results, the group of 26- to 35-yearolds consistently demonstrated high levels of knowledge on folic acid and its link with NTDs.

However, in view of the high incidence of NTDs (30.1/10 000 births) in Turkey ${ }^{2}$, there is an urgent need to change the knowledge and behaviour of Turkish women, who seem to be unaware of the risks. Direct health costs for children with spina bifida could be up to $\$ 1.7$ million a year. These costs do not account for the physical and emotional stress on the families nor do they reflect the lost economic potential associated with NTDs ${ }^{27}$. A government-led education campaign is needed, with material targeted to women who are thinking about pregnancy and to women who are able to get pregnant even though they are not planning on it in the near future. Health education concerning dietary intake and folate supplements continues to be essential. Educators must know the knowledge, attitudes and behaviours of women regarding folate intake. It is also worthwhile noting that a population increase in folic acid intake also has a protective effect on heart disease and cervical and colorectal cancers ${ }^{28}$.

To increase folate intake among women of childbearing age, mandatory folate fortification of enriched grain products (e.g. bread, cereals, pasta, flour, rice and cornmeal) must be introduced in Turkey. Folate fortification of grain products will be very important in preventing $\mathrm{NTDs}^{27}$. In Canada, white flour is fortified with folic acid so that $100 \mathrm{~g}$ of flour provides $0.15 \mathrm{mg}$ of folic acid. This fortification is estimated to meet $25 \%$ of the recommendation of folic $\mathrm{acid}^{28}$. Food fortification may be more effective for vitamin supplementation than focusing on education $^{29}$.

In conclusion, the results of this study show that increased public education concerning folic acid and prevention of NTDs is needed. Dietetics professionals should be encouraged to work with others (medical and public health professionals) to develop educational materials and to implement educational activities to all women of childbearing age. Follow-up studies should measure behaviour change related to education on folic acid.

\section{References}

1 Butterworth CE, Bendich A. Folic acid and the prevention of birth defects. Annual Review of Nutrition 1996; 16: 73-97.

2 Tunçbilek E, Boduroğlu K, Alikaşifoğlu M. Neural tube defects in Turkey: prevalence, distribution and risk factors. Turkish Journal of Pediatrics 1999; 41: 299-305.

3 Committee on Genetics. Folic acid for the prevention of neural tube defects. Pediatrics 1999; 104(2): 325-7.

4 EUROCAT Working Group. 15 Years of Surveillance of Congenital Abnormalities in Europe 1980-1994. Report No. 7. Brussels: Scientific Institute of Public Health-Louis Pasteur, 1997; 50-79.

5 Cornel MC, Erickson JD. Comparison of national policies on periconceptional use of folic acid to prevent spina bifida and anencephaly. Teratology 1997; 55: 134-7.

6 Bailey LB. New standard for dietary folate intake in pregnant women. American Journal of Clinical Nutrition 2000; 71(Suppl.): 1304S-7S.

7 Winship KA, Cahal DA, Weber JCP, Griffin JP. Maternal drug histories and central nervous system anomalies. Archives of Disease in Childhood 1984; 59: 1052-60.

8 Mulinaire J, Cordero JF, Erickson JD, Berry RJ. Periconceptional use of multivitamins and the occurrence of neural tube defects. Journal of the American Medical Association 1988; 260: 3141-5.

9 Bower C, Stanley FJ. Dietary folate as a risk factor for neuraltube-defects: evidence from a case control study in western Australia. Medical Journal of Australia 1989; 150(11): 613-9.

10 MRC Vitamin Study Research Group. Prevention of neural 
tube defects: results of the Medical Research Council Vitamin Study. Lancet 1991; 338: 131-7.

11 Centers for Disease Control. Recommendations for the use of folic acid to reduce the number of cases of spina bifida and other neural tube defects. Morbidity and Mortality Weekly Report 1992; 41: 1-7.

12 Werler MM, Shapiro S, Mitchell AA. Periconceptional folic acid exposure and risk of occurrent neural tube defects. Journal of the American Medical Association 1993; 269: $1257-61$.

13 Czeizel AE, Dudas I, Metneki J. Pregnancy outcomes in a randomised control trial of periconceptional multivitamin supplementation. Archives of Gynecology and Obstetrics 1994; 255(3): 131-9.

14 Bendich A. Folic acid and prevention of neural tube defects: critical assessment of FDA proposals to increase folic acid intakes. Journal of Nutrition Education 1994; 26: 294-9.

15 Wald NJ, Bower C. Folic acid and the prevention of neural tube defects. British Medical Journal 1995; 310: 1019-20.

16 Shaw GM, Schaffer D, Velie EM, Morland K, Harris JA. Periconceptional vitamin use, dietary folate, and the occurrence of neural tube defects. Epidemiology 1995; 6: 219-26.

17 Food and Agriculture Organization (FAO). Nutrition Country Profiles, Turkey. Rome: FAO, 2000.

18 Ungan S, Ünsalan R, Kaynak K. Türkiye'de gıda tüketim harcama ve kompozisyon verileri analizi. Ankara: Araştırma sempozyumu, 1998.

19 Pekcan G, Karaağaoğlu N. State of nutrition in Turkey. Paper presented at Workshop on Promoting Food-based Dietary Guidelines and Nutrition Education in the Near East Region, Amman, 16-19 November 1998.

20 Daly LE, Kirke PN, Mollay A, Weir DG, Scott JM. Folate levels and neural tube defects: implications for prevention. Journal of the American Medical Association 1995; 274: 1698-702.

21 Gregory JF. Bioavailability of folate. European Journal of Clinical Nutrition 1997; 51(Suppl.): S54-9.

22 Pfeiffer CM, Rogers LM, Bailey LB, Gregory JF. Absorption of folate from fortified cereal-grain products and supplemental folate consumed with or without food determined by using a dual-label stable-isotope protocol. American Journal of Clinical Nutrition 1997; 66: 1368-97.

23 Brouwer IA, Dusseldorp M, West CE, Meyboom S, Thomas CMG, Duran M, et al. Dietary folate from vegetables and citrus fruit decreases plasma homocysteine concentrations in humans in a dietary controlled trial. Journal of Nutrition 1999; 129: 1135-9.

24 Kim YI. Folate and cancer prevention: a new medical application of folate beyond hyperhomocysteinemia and neural tube defects. Nutrition Reviews 1999; 57(10): 314-21.

25 Centers for Disease Control. Folic acid campaign and evaluation - Soutwestern Virginia, 1997-1999. Morbidity and Mortality Weekly Report 1999; 48(40): 914-8.

26 Kloeblen AS. Folate knowledge, intake from fortified grain products, and periconceptional supplementation patterns of sample of low-income pregnant women according to the Health Belief Model. Journal of the American Dietetic Association 1999; 99(1): 33-9.

27 Reisch HS, Flynn MAT. Folic acid and the prevention of neural tube defects. Canadian Journal of Public Health 2002; 93(4): 254-8.

28 Beresford SAA. How do we get enough folic acid to prevent some neural tube defects? American Journal of Public Health 1994; 84: 348-50.

29 Frishman GN, Spurrell TP, Heber WW. Folic acid preconception knowledge and use by infertile women. Journal of Reproductive Medicine 2001; 46(12): 1025-30. 